\title{
NEMATODOFAUNA OF POTATO TUBERS IN THE REPUBLIC OF MOLDOVA
}

\author{
Maria Melnic \\ Institute of Zoology, Chisinau, Republic of Moldova \\ email: mariamelnic232@gmail.com
}

\begin{abstract}
According to the multiannual researches, it was observed that, in the conditions of the Republic of Moldova, the Nematodofauna of potato tubers (Solanum tuberosum) of different varieties, collected from deposits, is specific, with the dominance of saprophytes due to the spread of bacteriosis and fungal infections. In the potato tubers, sick with dithylenchosis (phases 4, 5), the presence of 30 spec8es of nematoodes was identified, belonging to 24 genera, 14 families, 5 orders, 2 classes: 1. Class Secernentea, Orders Aphelenchida, Rhabditida and Tylenchida; 2. Class Adenophorea, Orders Dorylaimida and Plectida. Most species (19 species) are saprophytes of the Class Secernentea, Order Rhabditida with the dominance of the Superfamilies Cephaloboidea and Diplogasteroidea. According to the trophic-ecological group, the species detected in the potatoes tubers are included in all 5 groups: plant feeding, hiphal feeding, bacterial feeding, animal predation, omnivorous. In all researched varieties, both in frequency (100\%) and density (thousands of individuals/gram of infested tissue) distinguished species Ditylenchus destructor Thorne 1945, Order Tylenchida, Family Anguinidae, which is also the main parasite in the culture of Solanum tuberosum in the Republic of Moldova, capable of causing dithylenhosis, as well as epiphytotics - mass infestation of potatoes in deposits.
\end{abstract}

\section{Introduction}

In the Republic of Moldova, one of the main crops are potatoes - Solanum tuberosum. There are currently about 4.000 varieties and hybrids on the world market. It is cultivated in almost all countries around the world on a total area of 18.8 million ha [10]. Potatoes are valued for their rich content of carbohydrates - starch (95-99\% of total carbohydrates), proteins, fats, vitamins B1, B2, PP, provitamin A, significant amounts of trace elements - K, P, Na, Ca, Fe, etc., which are necessary for the existence of the human body. Among the main foods it ranks 4-th after wheat, rice, corn. It is a product not only of food importance but also fodder, industrial, ecological, etc. In the Republic of Moldova, the largest areas with potato cultivation are located in the northern districts. Favorable conditions for potato cultivation are also favorable for a large number of their pests. Among the most dangerous are phytoparasitic nematodes, which form cyst - Globodera rostochiensis, G. pallida and migratory endoparasites - tuber nematode - Ditylenchus destructor, included in the list of quarantine species [7]. It is a host plant of sedentary nematodes of the genus Meloidogyne - M. hapla, M. javanica, M. hispanica, M. incognita, M. arenaria $[15 ; 9]$. Dithylenhosis disease, caused by potato tubers and seeds by the parasitic nematode $D$. destructor, is widespread in all agro-climatic areas of the world, and the decrease in yields under certain conditions reaches $43 \%$ [14].

It is important to mention that in the tubers infested by D.destructor, a very important role belongs not only to the phytoparasitic species, but also to other nematode species, such as the saprophytic ones. These are active inoculators of bacterial and fungal infections, being secondary factors of dithylenosis. It is they that cause the disease of potatoes to pass into the mycosis and bacteriosis. Potatoes are also attacked by a complex of pathogenic potato viruses, including 
quarantine - TBRV and TRV, fungi, which cause root mold, bacteria and a. [19]. According to previous research, in the culture of food potatoes in the Republic of Moldova, the presence of a single species of phytoparasitic nematodes was detected - D. destructor, studied the morphological structure and indicated some measures and methods to combat it $[2 ; 6 ; 12 ; 16]$. In parallel, ecological-physiological research was performed on t2he interrelationships between the phytoparasitic nematodes Meloidogyne incognita, Ditylenchus destructor and D. dipsaci with their host plants - tomatoes, potatoes, Allium crops $[3 ; 4 ; 5]$.

The current research, unlike the previous ones, is carried out on different varieties of potatoes, which are widely grown in the republic in recent years, in the districts of North, Center and South - Agata, Albăstriu-mov, Bellarosa, Desiree, Irga, Iagodca, Kondor, Roko, Romano, Sprinter. A total of 10 varieties, the objectives being: the evaluation of the biodiversity of the communities of parasitic and saprophytic nematodes in the potato tubers in the autumn-winter-spring period; highlighting the obligatory species of pests of potatoes and the damage caused by them.

\section{Material and methods}

The evaluation of the diversity and structure of the communities of parasitic and free phytonematodes was performed on the potato tubers, collected from: the districts of the Northern area (Briceni, Dondiuşeni, Edineţ, Soroca); of the Center (Criuleni, Telenesti, Ialoveni districts); South (Ştefan-Vodă district). Samples of potato tubers were collected, in most cases, from individual households in the autumn-winter- spring period (after harvest, or stored in warehouses), about 15-30 tubers/sample, depending on the amount of potatoes investigated. 10 varieties of potatoes origin from locals or coming from abroad were researched. Faunistic material was obtained by the classical method of extracting nematodes from plant tissue using Baermann funnels, modified by Nesterov [17]. Before being analyzed, the collected tubers were thoroughly washed with tap water, then the portions with symptoms of dithylenosis disease were shredded with a scalpel into pieces the size of $-5 \times 5 \mathrm{~mm}$. For each sample, 20 grams of infested tissue were weighed, which was then introduced into household sieves. The sieves were immersed in funnels, filled with water, so that the potato particles were covered. The exposure time was 48 hours. The faunistic material obtained was fixed with hot formalin (by 60 o C) with a concentration of $4 \%$, and further used for the assembly of permanent preparations according to the Seinhorst method, by transferring nematodes to glycerin [1].

\section{Results and discussions}

The potato tuber nematodofauna was first investigated in the Republic of Moldova. In the research process it was observed that the nematodofauna, formed in the tubers in the deposits, is specific, with the dominance of saprophytes, due to the spread of bacteriosis and mycosis infections. As a result of the analyzes, carried out for several years, in the potato tubers was detected the presence of 30 species of nematodes (tab. 1), which belong to 24 genera, 14 families, 5 orders, 2 classes: 1. Class Secernentea - orders Aphelenchida, Rhabditida, Tylenchida; 
2. Class Adenophorea - orders Dorylaimida, Plectida. Most of the species detected (19 species) are of the order Rhabditida with the dominance of the superfamily Cephaloboidea - Acrobeloides buetschlii, Heterocephalobus elongatus, Eucephalobus striatus, Panagrolaimus rigidus; the Rhabditoidea superfamily- the Rhabditis, Mesorhabditis and Diplogasteroidea superfamily with the dominance of the Pristionchus lheritieri species; 4 species of the order Aphelenchida, with the dominance of Aphelenchus avenae; 3 species of the order Tylenchida, dominated by Ditylenchus destructor; 2 species of the order Dorylaimida - Aporcelaimellus obtusicaudatus and Mesodorylaimus bastiani; 1 species of the order Plectida - Anaplectus granulosus. Aporcelaimellus obtusicaudatus is known to be omnivorous, but according to the trophic-ecological classification [11] it is also included in the group of omnivorous and in the group of animal predation, which indicates that this species is attracted to potatoes diseased by dithylenosis, by the surplus of parasitic nematodes and saprophytes present in this environment. M. bastiani species is not specific for potato tubers, she enters by the paths formed by wire larvae. Of the order Plectida, only one species - Anaplectus granulosus - was present in potatoes suffering from dithylenosis. From the order Tylenchida, as mentioned, there were 3 species: the first species - Ditylenchus destructor Thorne 1945, which is also the main obligatory parasite of the potato crop Solanum tuberosum in the Republic of Moldova (tab. 1; fig. 1). The species D.destructor differed both in frequency $(100 \%)$ in all varieties studied and by density (thousands of individuals/gram of infested tissue), able to provoke dithylenosis disease, as well as epiphytotics - mass infestation of potato from warehouses.
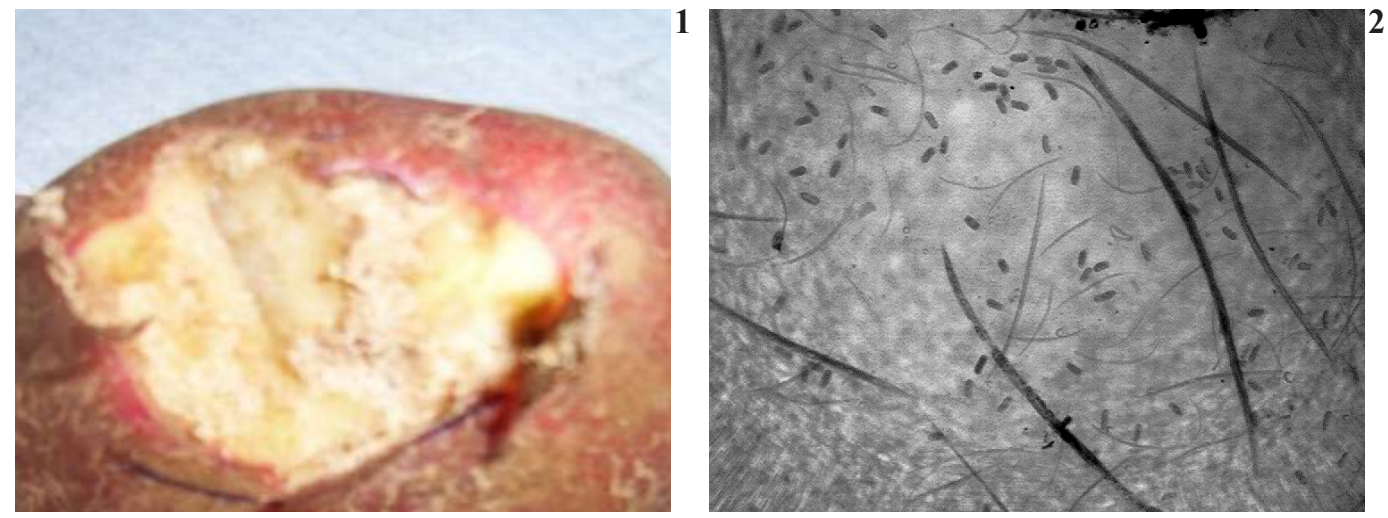

Figure 1. Infested Roko potato (storage period) infested, phase 2 of ditylenchosis (1); population D.destructor (2) (females, males, larvae, eggs), which was extracted from the infested tissue

It is necessary to mention that the second phytoparasitic species - D.dipsaci, is quite rare in potato tubers. Of the 10 varieties investigated, this species was found in association with the D.destructor species only at 3 of them - Bellarosa, collected from Ştefan-Vodă district and Desiree and Irga, collected from the north of the republic (Edinet district). The species Tylenchus davainei was common in some varieties of tubers. This is a migrating root ectoparasitic species, which accidentally hit the potato tubers. All 30 species, detected in potato tubers, according to the trophic-ecological characteristic [11], are included in the following 5 groups: 
plant feeding (Pf); hiphal feeding (Hf); bacterial feeding (Bf); animal predation (Ap); omnivorous (Om) (tab. 1; fig. 2).

The group of phytophagous includes the species Ditylenchus destructor, D.dipsaci and Tylenchus davainei which account for $7.41 \%$. D. destructor species is the only species of obligatory phytoparasites of potato tubers in the Republic of Moldova, which causes them dithylenosis (fig. 2). Because it parasitizes mainly only in the potato tubers, causing their disease of dithylenhosis, it was also called the tuber nematode. Other species of obligatory parasitic nematodes were not detected in the researched tubers, which confirms that in the conditions of the Republic of Moldova, namely $D$. destructor is the pathogen of dithylenhosis in potatoes in autumn-winter- spring.

Table 1. Biodiversity of phytonematodes in potato tubers of different varieties, infested by

D.destructor, according to the phases of dithylenosis and trophic-ecological groups

\begin{tabular}{|c|c|c|c|c|}
\hline No. & Nematode species & $\begin{array}{l}\text { Phases } \\
1,2 \text { of } \\
\text { dithyle- } \\
\text { nosis }\end{array}$ & $\begin{array}{c}\text { Phases } \\
3,4 \text { of } \\
\text { dithyle- } \\
\text { nosis }\end{array}$ & $\begin{array}{l}\text { Trophic- } \\
\text { ecological } \\
\text { groups }\end{array}$ \\
\hline & Class SECERNENTEA:1.Order Tylenchida & & & \\
\hline 1. & Ditylenchus destructor & +++ & ++ & $P f$ \\
\hline 2. & Ditylenchus dipsaci & - & + & $P f$ \\
\hline \multirow[t]{2}{*}{3.} & Tylenchus davainei & - & + & $P f$ \\
\hline & 2. Order Aphelenchida & & & \\
\hline 4. & Aphelenchus avenae & - & + & $H f$ \\
\hline 5. & Aphelenchus eremitus & - & + & $H f$ \\
\hline 6. & Aphelenchoides asterocaudatus & - & + & $\boldsymbol{H f}$ \\
\hline 7. & Aphelenechoides parietinus & - & + & $H \boldsymbol{H}$ \\
\hline \multirow[t]{2}{*}{8.} & Seinura demani & - & + & Ap \\
\hline & 3. Order Rhabditida & & & \\
\hline 9. & Bunonema sp. & - & + & $B f$ \\
\hline 10. & Acrobeles ciliatus & - & + & $B f$ \\
\hline 11. & Acrobeloides buetschlii & - & + & $B f$ \\
\hline 12. & Cephalobus persegnis & - & + & $B f$ \\
\hline 13. & Chiloplacus propinguus & - & + & $B f$ \\
\hline 14. & Chiloplacus symmetricus & - & + & $B f$ \\
\hline 15. & Eucephalobus mucronatus & - & + & $B f$ \\
\hline 16. & Eucephalobus striatus & - & + & $B f$ \\
\hline 17. & Heterocephalobus elongatus & - & + & $B f$ \\
\hline 18. & Diplogasteroides spengelii & - & + & $B f$ \\
\hline 19. & Diploscapter coronatus & - & + & $B f$ \\
\hline 20. & Pristionchus lheritieri & - & + & $B f, A p$ \\
\hline
\end{tabular}




\begin{tabular}{|c|l|c|c|c|}
\hline $\mathbf{2 1 .}$ & Panagrolaimus rigidus & - & + & $\boldsymbol{B f}$ \\
\hline $\mathbf{2 2 .}$ & Caenorhabditis elegans & - & + & $\boldsymbol{B f}$ \\
\hline $\mathbf{2 3 .}$ & Mesorhabditis signifera & - & + & $\boldsymbol{B f}$ \\
\hline $\mathbf{2 4 .}$ & Pelodera teres & - & + & $\boldsymbol{B f}$ \\
\hline $\mathbf{2 5 .}$ & Rhabditis longicaudata & - & + & $\boldsymbol{B f}$ \\
\hline $\mathbf{2 6 .}$ & Protorhabditis filiformis & - & + & $\boldsymbol{B f}$ \\
\hline $\mathbf{2 7 .}$ & Protorhabditis sp. & - & + & $\boldsymbol{B f}$ \\
\hline & Class ADENOPHOREA 1.Order Plectida & & & \\
\hline $\mathbf{2 8 .}$ & Anaplectus granulosus & - & + & $\boldsymbol{B f}$ \\
\hline & 2. Order Dorylaimida & & & \\
\hline $\mathbf{2 9}$. & Aporcelaimellus obtusicaudatus & - & + & $\boldsymbol{O m}, \boldsymbol{A p}$ \\
\hline 30. & Mesodorylaimus bastiani & - & + & $\boldsymbol{O m}$ \\
\hline Total species: & & $\mathbf{1}$ & $\mathbf{3 0}$ & \\
\hline
\end{tabular}

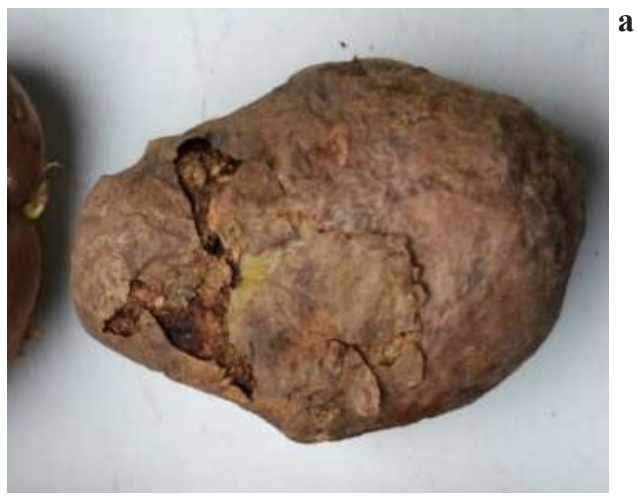

Figure 2. Distribution of nematode species in the Desiree potato tuber, sick of ditylenchosis (phases 3, 4) (a), by trophic-ecological groups (b): Pf -7.41\%; Hf -14.81\%; Ap - 3.7\%, Bf $-74.1 \%$

It is necessary to mention that the presence of the nematode that forms cysts - Globodera rostochiensis, in the samples we investigated, was not detected. From the group of animal predation (Ap, type 5b) was detected only one species - Seinura demani (3,7\%), the order Aphelenchida, the family Seinuridae which, as it is known, is able to devour and feed on other species of nematodes, including those in the group of bacteriophages - Acrobeloides, Chiloplacus, Plectus and mycelium-hypophagous group - some species of the genus Aphelenchoides, whose presence is quite common in the macerated tissue of tubers. The trophic-ecological group of hiphal feeding (Hf) includes species, which are directly dependent on the presence of fungal mycelium, where they find the right habitat and with which they feed - Aphelenchus avenae, Aphelenchus eremitus, Aphelenchoides asterocaudatus, Aphelenchoides sp., permanently common being Aphelenchus avenae. According to our recalculations, they account for $14,80 \%$ of the total species (fig. 2b). Unlike bacteriovore species, which do not have a stylet, hiphal feeding species of the order Aphelenchida are endowed with a small stylet, which in 
the process of nutrition pierces the cell wall of the hyphae of fungi and absorbs their contents. Aphelenchus avenae is listed as one of the most common nematodes in the soil. According to its geographical distribution, it is a ubiquitous species. According to some authors, A.avenae is able to feed and reproduce in mycosis-infested tissue caused by pathogenic fungi - Verticillium, Fusarium (Fusarium solani var coeruleum, F.sambucinum, F.oxysporum), Alternaria, Rhizoctonia solani and a., which causes serious diseases, both in plants and in potato tubers, being permanently frequent in potato tubers in warehouses, infested by D.destructor in the advanced stages of dithylenhosis [8, 13, 18].

Finally, the most numerous and frequent in the affected tubers are the species from the group of bacterial feeding - 19 species, which have the highest percentage $-74.1 \%$. These are included in 17 genera: Bunonema, Acrobeles, Acrobeloides, Cephalobus, Eucephalobus, Chiloplacus, Heterocephalobus, Diplogasteroides, Diploscapter, Pristionchus, Panagrolaimus, Caenorhabditis, Pelodera, Rhabditis, Mesorhabditis, Protorhabditis, Anaplectus (Table 1). Most of the species of bacterial feeding nematodes, detected in the potato tubers researched by us -Cephalobus persegnis, Chiloplacus propinguus, Eucephalobus striatus, Acrobeles ciliatus, Panagrolaimus rigidus, Diploscapter coronata etc., as well as some mycophagous species - Aphelenchus existence are ubiquitous and euribionts.

It is necessary to mention that the saprophytic nematodes do not have a stylet, and the mode of nutrition takes place by swallowing the primary products, which result under the action of the saprobiotic microflora, so it does not pose a danger to the potato tubers, but in association with the species of parasites mandatory - nematodes Ditylenchus destructor, D.dipsaci and bacteria and fungi increase the putrefaction processes of the affected tissue and its total destruction. In such dead plant tissue, phytoparasitic nematodes, which feed only on live plant tissue, do not resist and move to the soil, where they are kept for a long time - 3-4 years. Along with the seed tubers, which are the first source of potato infestation, the infested soil is also a way of transmitting parasitic nematodes to the potato culture, which is also a moment of widening of the infested surfaces. The nematode Ditylenchus destructor is considered, globally, among the most dangerous pests in potato culture, being included in the list of quarantine species [7]. At the same time, it is known that potato tubers, compared to other vegetative organs of this crop, contain an increased amount of water, so in dry years they are primarily attacked by various pests, including bacterial infections, fungal infections, parasitic nematodes and saprophytes, mites, etc.

The studies were carried out within the research project no. 20.80009.7007.12.

\section{Conclusions:}

1. Nematological analysis of potato tubers of 10 varieties, collected in the autumn-winter-spring periods, showed the presence of 30 species of nematodes, most - 19 species, being of the order Rhabditida. The species Pristionchus lheritieri was distinguished by dominance, family Neodiplogasteridae.

2. The species, detected in the tubers of potatoes diseased with dithylenhosis, the advanced 
phases - 3, 4, according to the trophico-ecological characteristic, are included in all 5 groups: plant feeding, hiphal feeding, bacterial feeding, animal predation, omnivorous.

3. Ditylenchus destructor Thorne 1945, which is also the main parasite in the potato crop in the Republic of Moldova, the cause of the disease, was distinguished by frequency $(100 \%)$ in all 10 researched varieties and by density (thousands of individuals/gram of infested tissue), able to provoke ditylenchosis disease, as well as epiphytotics - mass infestation of potato from deposit.

\section{Bibliography}

1.Bezooigen J. V.2006. Methods and techniques for nematology. Publisher, Wageningen University.Netherlands. $112 \mathrm{pp}$.

2.Bumbu I. Aspecte ecologo-fiziologice privind interacţiunea nematozilor fitoparaziţi cu planta-gazdă. Autoreferatul tezei de doctor habilitat în şt. biologice.Chişinău,1998.-49 pp.

3. Bumbu I.V. Patogeneza și combaterea fitonematodozelor. Chişinău: U.T.M., 2009, -164 pp. ISBN 978-9975-45-099-7.

4. Melnic M. Nematoda culturilor Allium. Chişinău: Promarcos, 2008. 168 pp. ISBN 978-9975105-05-7.

5. Melnic M., Erhan D., Rusu Ş., Toderaş I, Chihai N. Nematoda tuberculilor de cartof, patologii morfo-fiziologice şi bioindicări ale stării fitosanitare//Buletin ştiinţific Revistă de Etnografie, Ştiinţele Naturii şi Muzeologie, Chişinău, 2015, Vol.22(35), -p.35-44. ISSN 1857-0054.

6. Melnic M., Toderaș I., Erhan D., Rusu Ş., Onoraș L., Todiraș V. Metode de combatere şi profilaxie a nematodelor parazite la cultura cartofului: Recomandări practice. Chişinău : I.E.P Ştiinţa, 2014 (Tipografia „BALACRON” SRL), 40 pp. ISBN 978-9975-67-919-0.

7. OEPP / EPPO.2008.Ditylenchus destructor and Ditylenchus dipsaci// Buletin 38: 363-373.

8. Rojankovski E., Ciurea A. Contributions to the study of interactions between the potato rot nematode Ditylenchus destructor Thorne, and fungi in the potato disease complex // Arch. Phytopathol. Pflanzenschutz, Berlin 22 (1986) 2, 101-106.

9. Santos MSN de A., Rodrigues ACF de O., Abrantes IM de O. Root-knot nematodes, Meloidogyne spp., on potato, in Portugal // Nematologica. -1992, v.38, no 4.-C.433-434.

10.Starodub V., Gheorghiev N. Plantele tuberculifere şi rădăcinoase. Fitotehnie, „Museum”. Chişinău, 2008, p. 312-330.

11.Yeates GW, Bongers R.G., Goede R.G.M, Frecman D.W and Georgieva S.S. 1993. Feeding habits in soil nematode families and genera-an outline for soil ecologists // Journal of Nematology. № 25 (3): 315-331.

12.Dементьева С.П. Стеблевая нематода картофеля. Кишинев :Штиинца, 1980. -28 С.

13.Зейрук В.Н. Болезни, вредители и сорняки картофеля. wwwboyercropscience.ru.

14.Иванюк В.Г., Ильяшенко Д.А.Устойчивость картофеля к стеблевой нематоде (Ditylenchus destructor Thorne). Весці нац. Академіі навук Беларусі, 2010, № 3, p.43-48.

15.Кирьянова Е.С., Краль Э. Паразитические нематоды растений и меры борьбы с ними. Ленинград: Наука.1971, том II, 521 рр.

16.Нестеров П.И.Фитонематоды вредители культурных растений Молдавии.- Кишинев: РИО АН МССР, 1970.-38 С.

17.Нестеров П.И. Фитопаразитические и свободноживущие нематоды юго-запада СССР. Chisinau: Штиинца, 1979, 277 pp.

18.Протопопов Г.А.Нематодофауна картофеля пораженного микозами и бактериозами в Карельской АССР и Московской области. Бюллетень Всесоюзного института гельминтологии им. К. И. Скрябина. 1971, вып. 6, р. 65-72.

19.Романенко Н.Д. Паразито-хозяинные взаимоотношения микробных консорбентов агроценоза как основа стратегии его. Москва: Наука, 2004, -с.152-170. 